\begin{tabular}{|c|c|}
\hline DOSSIER & $\begin{array}{l}\text { TECHNOLOGICAL } \\
\text { CONVERGENGE AND THE } \\
\text { NEW IOURNALIST }\end{array}$ \\
\hline $\begin{array}{l}\text { ght } 1 \text { ( } 2013 \\
\text { Asssociacáa } \\
\text { rasaileira de } \\
\text { sadores em } \\
\text { Jornalismo }\end{array}$ & $\begin{array}{l}\text { DAVID RENAULT } \\
\text { Universidade de Brasilia }\end{array}$ \\
\hline
\end{tabular}

\begin{abstract}
Beginning in the 1990s, Brazilian means of communication have experienced a (still ongoing) transformation process in the treadmill of technological advances, which have allowed for broad media convergence and for a single journalistic group to offer diverse products across various digital platforms. These transformations have impacted profoundly the routines of journalistic newsrooms and their professionals, from whom more and more agility is expected in order to meet the demands of the new era. This study seeks to demonstrate how the new reality affects the routines of newsrooms and journalists at the Brasilia offices of four of the most prominent newspaper groups in the country: O Estado de S. Paulo, Folha de S. Paulo, Valor Econômico and O Globo.
\end{abstract}

Keywords: Journalists. Journalistic production. Media convergence. Brasilia office.

\title{
A CONVERGÊNCIA TECNOLÓGICA E O NOVO JORNALISTA
}

RESUMO - A partir da década de 1990, os meios de comunicação brasileiros iniciaram um processo de transformação que ainda está em andamento, na esteira dos avanços tecnológicos, que permitiram uma ampla convergência das mídias e que um mesmo grupo jornalístico ofereça produtos diversos em várias plataformas digitais. Essas transformações atingiram profundamente as rotinas das redações jornalísticas e seus profissionais, dos quais se espera cada vez mais agilidade para atender às demandas desses novos tempos. Este trabalho procura mostrar como a nova realidade atinge a rotina das redações e os jornalistas da sucursal de Brasília de quatro dos principais grupos que controlam jornais impressos no país: O Estado de S. Paulo, Folha de S. Paulo, Valor Econômico e O Globo.

Palavras-chave: Jornalistas. Produção jornalística. Convergência das mídias. Sucursal de Brasília.

\section{LA CONVERGENCIA TECNOLÓGICA Y EL NUEVO PERIODISTA}

RESUMEN - A partir de la década de los noventa, los medios de comunicación brasileños iniciaron un proceso de transformación, que aún está en curso, siguiendo la estela de los avances tecnológicos que han permitido una amplia convergencia de los medios y que un mismo grupo periodístico ofrezca diversos productos en diferentes plataformas digitales. Estas transformaciones han afectado profundamente a las rutinas periodísticas y a sus profesionales, de los cuales se espera cada vez mayor agilidad para atender las exigencias de los nuevos tiempos. Este trabajo pretende mostrar cómo influye la nueva realidad en la rutina de las redacciones y en los periodistas de la delegación de la ciudad Brasilia de cuatro de los principales grupos que controlan los periódicos impresos del país: O Estado de S. Paulo, Folha de S. Paulo, Valor Econômico y O Globo.

Palabras clave: Periodistas. Producción de noticias. Convergencia de medios. Sucursal de Brasilia. 


\section{INTRODUCTION}

Ever since the main Brazilian newspapers began operations with information services in real time in the 1990s, their newsrooms and professionals have experienced profound transformations, offering the public diverse and unique products in an irreversible process of media convergence, as demonstrated in the works of Brazilian (Adghirni \& PEREIRA, 2011, Fonseca \& Kuhn, 2009, Moretzsohn, 2002), as well as foreign, scholars (Neveu, 2001, Ruellan, 2006 \& Wolton, 2004), amongst others.

Whilst seeking information for the research project "The perspective from journalistic teaching and practice in Brazil: the end of compulsory diplomas for journalists", registered at the CNPq (National Council for Scientific and Technological Development) and initiated in 2011, the research corpus of which is the Federal District, a profound transformation in the production routines of newsrooms and journalists in Brasilia was identified, represented by the implantation of digital platforms via means of communication. This transformation was brought about mainly due to the offices of printed newspapers, whose main task is to produce daily coverage of "issues of national interest" in politics, economics, legal affairs, health and education, amongst others, which practically dominate the working agenda of Brazilian newsrooms.

At the beginning of 2013, a new study was undertaken to update information obtained previously. Its main corpus is the newsrooms and professionals at the Brasilia offices of: O Estado de S. Paulo, Folha de S. Paulo and Valor Econômico, headquartered in São Paulo City, and O Globo (Rio de Janeiro), in addition to Correio Braziliense, since it is the capital's main newspaper. The aim was to identify how media convergence has affected, and could yet affect, older professionals with experience of two decades or more, as well as younger ones, who began more recently.

Hence, the general aim of this study is to discuss how structural changes to journalism affect the production routines at the Brasilia newsrooms of the newspapers analyzed. For several years, daily, printed newspapers have sought to survive in a new context typified by competition from different media, the decrease in commercial publicity and the crucial need to apply new business models to cope with operational costs and ensure the profitability of companies.

The problem is that within this context characterized by sharp changes in production routines and newsworthiness values and criteria, journalistic companies have cut their workforces, whilst testing and 
implanting business models demanding a new approach, dynamic and workrate from professionals on a daily basis. These new models include attempts to charge for online content and the offer of unique, exclusive, paid products to specific and highly qualified subscribers, usually executives working in finance or at public and private organizations. The system is conventionally referred to as real time, the quickest possible spread of information from the moment events occur.

This new scene entails an adverse factor: the need to reduce general costs involves cutting workforces in newsrooms, which, moreover, are increasingly occupied by young journalists receiving lower salaries, who have replaced more experienced professionals. In the case of the Brasilia newsrooms analyzed, a same professional assumes the task of gathering, drafting and transmitting information on diverse platforms to keep sites updated, in the quickest possible time between the occurrence of events and their availability, as well as providing subsequently additional details. At the end of a workday, journalists still need to contribute to the printed publication to be distributed on the following day.

As part of this study, personal interviews were conducted with directors and coordinators from the four aforementioned offices, as well as the Correio Braziliense office, between the second half of March and the first half of April.1 Further, six reporters from the four offices, aged over 50 and with over 20 years' experience of journalism in Brasilia, were interviewed along with six other reporters aged between 22 and 30, with less than 10 years in the profession. 2

The answers to the semi-structured interviews, with specific questions addressed to all, were grouped together into topics throughout the text in an attempt to outline different points, from the nature of daily routines, the need to work simultaneously on sites and printed publications, the companies' business plans, the issue of "scoops" and exclusive stories, to the difficulty older professionals face in managing digital tools and the mastery younger workers have over them.

\section{STRUCTURAL CHANGES}

The Canadian authors Brin, Charon and Bonville compiled the book "Nature and transformation of journalism. Theories and empirical studies" (2004), in which, along with other scholars, they seek to analyze the transformations in journalism and journalistic practice, from the origins of the press in North America up until the 21st century. 3 They 
identify four main historical periods, characterized by specific ways to conceive of and practice journalism, called journalistic paradigms.

The first of these periods began with the emergence, in the 17th century, of what scholars have identified as transmission journalism, whereby printers disseminated in their gazettes adverts, notices and correspondence, amongst other things, functioning essentially as the link between original information sources and readers. The discursive identity of "gazetteers" or journalists began in the 19th century, with the emergence of opinion journalism, whereby newspaper owners, now the editors, though with modest readerships and without commercial aspirations, put their vehicles at the service of political battles.

Also according to the authors, already by the end of the century, with increases in population and literacy rates, the growth of business, advertizing and the possibility of gathering news using means such as the railways, telegraph and telephone, newspapers started to become a profitable business, particularly as circulation increased with the offer of relevant news for the larger readership. Thus, information journalism surfaced between 1880-1910 and would later become universal and start to dominate journalism in the 1920s. It underwent yet further transformation, beginning in the 1970s, leaving the previous model for what the Canadian authors call communication journalism, with the arrival of new investors in a market characterized by the multiplication of media and their technological aids, diversification and the great supply of diverse products.

The transformation of journalism and acceleration of the convergence process are occurring increasingly rapidly around the world and in Brazil, via communication groups established decades ago and other, more recent groups that adopt new initiatives, ensuring the participation of new consumer markets, amidst the structural changes in journalism, which are provoking permanent transformation/reinvention.

Adghirni (2012: 66) explains that the changes in the rules for news production and consumption, competition, advertizing, the challenges posed by new technologies with technological convergence, "have provoked profound transformations in the manner of performing journalism", as shown in the works of Neveu and Ruellan, amongst others. Specifically within the communication department at UnB, this field has been the object of study for scholars such as Adghirni (2010, 2012), Jorge (2007, 2010), Müller (2012) and Pereira (2004, 2010).

Structural changes, in contrast to "conjunctural changes and micro-innovations that affect specific aspects of a social practice", are 
extensive and profound, altering "radically the way in which a certain activity is practiced and symbolically recognized/defined by the actors". Thus, a new newspaper layout, for instance, could change the way in which journalism is practiced but "it is unlikely to trigger a process of structural changes", such as the impact of the Internet's advent (ADGHIRNI and PEREIRA, 2011:42).

In addition to posts and functions that have survived to the present day, including reporters, editors, secretaries and editors-inchief, newsrooms incorporated assistant and sectoral reporters, newsgatherers (who, in the Brazilian context, undertook to gather and transmit quick news), and assistant writers. There were assignment editors, tasked with indicating what subjects would be researched during the day, title setters, specialists in creating titles at a time when newspapers were compiled by layout designers, using manual calculations in order to "close" the gaps in texts and photos, paginated by paginators, appearing in formats later forwarded to the photolytic section, before being printed and revised by the proof-reader, charged with correcting spelling and grammatical mistakes (RENAULT, 2011:104).

In contemporary times, a same professional exercises multiple functions. Multimedia journalists are swarmed by greater workloads and rigorous pressure to meet different deadlines to ensure specialized services for subscribers and the newspaper sites themselves, as well as the following day's printed newspapers. "Due to these new market demands, companies with multimedia profiles seek professionals with equally multimedia abilities, both in terms of recruiting and requalifying/ training workforces". Ultimately, a same professional must be "a master technician in order to produce content for television, radio, newspapers and the Internet" (FONSECA and KUHN, 2009:59).

It is the irreversibility of "media convergence", the "fusion" of the printed, television, radiophonic and electronic, markets, using mobile and interactive technologies via digital platforms", as defined by Jorge and Adghirni (2010). Journalistic convergence is also occurring amidst the generalized implantation of digital telecommunication technologies, which, as well as affecting the "technological, business, professional and editorial (aspects) of means of communication", have meant that journalists produce diverse content, distributed across multiple platforms, all with their own, unique language, encouraging an "integration of previously segregated tools, spaces, work methods and languages". (GARCIA AVILÉS 2009, apud Jorge and Adghirni, 2010:113).

Structural changes in journalism, particularly in newspapers, 
can be traced to the popularization of the Internet and the wide-ranging opportunities it offers. On several occasions, newspapers have grappled with and overcome challenges, drawing on their "competitive advantages and introducing innovations to the industrial sector (advances in terms of equipment and processes), journalistic production and the administrative and commercial spheres", as Carlos Müller explains (MÜLLER, 2012:145).

However, several decades ago, the share of newspaper participation in advertizing decreased, making way for other means, particularly television, though the vehicles were generally still "highly profitable", as Müller states. This changed at the turn of the 21st century, when productivity gains resulting from innovations in industry, for instance the shift from linotypes to direct recording onto graphic printing plates, and even from journalistic production, "had plateaued or slowed down a lot" (MÜLLER, 2012:158).

The group O Estado de S. Paulo was the first in Brazil to invest significantly in the sale of news and products (essentially economicfinancial information and diverse indexes) outwith printed pages in newspapers, at the beginning of the 1990s - before even putting news online - using archaic transmission equipment and reception modems.4 Currently, most Brazilian medium- and larger-scale newspapers (in line with a global phenomenon) have their own sites where they make available news and other products, paid or free, yet they are experiencing a dilemma.

Only a small portion of the advertizing that left the printed newspapers was adopted by digital media and difficulties even arise in defining how much the market is willing to pay for digital adverts, which, in most cases, can theoretically stand out more than those in printed publications. The question is simple: how and how much to charge without losing advertizing space and readers? Newspapers know that the heavy investments made in digital technology, in order simply to avoid lagging behind competitors, need to generate return but most of the gains still emanate from printed publications. Consequently, organizations run at a loss and there is huge pressure to make cuts, including in the workforce, and increase gains.

Also following a tendency that is common in other countries, particularly the United States, Brazilian newspapers have found it inevitable to charge for access to digital platforms and several are already doing or preparing for this. It is known that investments in the domain will be constant because technological evolution is permanent, as is the need to train and retrain staff. All of this involves costs that 
need to be paid through billings.

The semestral meeting of Grupo de Diários América (GDA) took place in April in Rio de Janeiro and the issue discussed was paid content on the Internet. One of the speakers was the American Ken Doctor, an analyst of new industries and author of Newsonomics, which discusses the developments of the digital age. He considers that, by the end of 2013 -within 18 months at most- all the digital versions of at least 600 newspapers will have a paywall, through which readers will access certain news items online but then pay to continue reading. 5

As Wolf explains, journalistic production involves the phases of gathering, selection and news presentation (WOLF, 2008). Journalism "is the professional activity devoted to collecting, treating and publishing information in periodical form, in a comprehensible, ethical, impartial and direct manner, contributing to the free circulation of ideas, rationales and communication in democratic societies" (JORGE, 2007:21). Nevertheless, these concepts are often trumped by the principles of urgency and speed, which govern news and service sites, in the desperate race to defeat competition.

\section{A CONTINUALLY TRANSFORMING PROCESS}

Importantly, all the newspapers analyzed here still grant all individuals some sort of free access to their sites, for the time being. Printed news from daily newspapers and that released throughout the day, can be read in full or in part. However, it is a matter of time before this changes, since shareholders of Brazilian organizations also consider irreversible the decision to charge for access to their digital content.

In the case of $\mathrm{O}$ Globo and Estado, some news from printed newspapers is available online free of charge, fully or partly, via prior registration. The Valor site also provides free access to some news published in printed newspapers, while Folha limits readers' access to 30 news items per month. They can then pay per extra item or become subscribers to Folha Online or the printed version. In all cases, readers can also access news that is posted during the day and have the possibility of a subscription which includes the online daily and printed newspapers throughout the week or just for several days.

As it stands, the current context makes it possible to identify clearly two distinct business models used in newspapers, which, in turn, result in unique routines in the journalistic coverage from Brasilia offices. On the one hand, there are groups like Estado and Valor Econômico, 
whose main trait is the production and provision of news, analyses and diverse quotations from national and international markets aimed at a specific, specialized audience: subscribers to Broadcast for the former, and to Valor Pro, for the latter. This group of subscribers, made up primarily of businessmen, executives and consultants from various domains, is accorded priority and needs to be catered for first, as quickly as possible. For them, a difference of seconds in obtaining information can signify profits or losses in a globalized economic-financial market, connected 24 hours a day across all continents.

The O Globo and Folha offices, despite also aiming to produce and transmit information rapidly, generally cater for readers who access the sites of printed vehicles, without targeting any specific audience, unlike Valor and Estado. These business models influence in different ways the production routines of the newsrooms analyzed in this study, as will be discussed.

Of the offices analyzed, it is O Estado de S. Paulo that has the most unique structure, with distinct professionals working in interdependent fashion for Estado and Agência, yet who are cooperative and integrated in the production routine, as the office director João Bosco Rabelo, explains. Agência Estado (AE) has a coordinator and four journalists who take turns in the newsroom at producing texts using information that they either receive from the reporting team in Brasilia or gather directly. A further nine reporters work on daily coverage. Estado has an editor-in-chief who organizes material concerning politics and national affairs, an economics coordinator, in addition to 13 reporters.

Valor was created in 2000 via an association between the groups Globo and Folha and is currently the country's most influential newspaper for economics, business and finance, with an average circulation of 61,800 copies, according to the National Association of Newspapers. Its competitors are also specialized vehicles, for instance Jornal do Comércio, Diário do Comércio e Indústria and Brasil Econômico, all of which have lower circulations. Valor emerged at a time of decadence for Gazeta Mercantil, one of the most traditional economic vehicles in Brazil, from where many professionals of the newspaper's first newsroom originated, many of whom remain to this day.

Why did Valor decide to invest heavily in a new business sector in which traditional competitors such as Estado and other foreign groups, like Bloomberg, were already present? As Cláudia Safatle (deputy newsroom director) explains, the newspaper has established itself and gained its market, in which there is little room to grow. In addition, one 
of the main sources of income for the newspaper is the annual balance sheets that the Anonymous Societies (AS) are required to publish in printed publications by law, though Congress could, at any point, pass a new law allowing these publications on digital media. 6 Nobody knows with certainty where the newspaper's billings could end up. Following an experimental year, Valor Pro, was opened up to subscribers last January.

By setting up Valor Pro, the group broadened considerably its newsroom at the headquarters in São Paulo. In Brasilia, the increase in staff was due to the presence of trainees. An initial selection of around 40 final-year students or recent graduates in journalism took place. For two months, they attended lectures, essentially on economics, finance and federal government affairs relevant to public and private economic-financial matters. During this period, they produced texts, were interviewed and ultimately selected- four at first and then another two. There was a year's training period, shadowing more experienced reporters in daily coverage in Brasilia.

In practice, the creation of Valor Pro in Brasilia provoked a revolution in the work logic and routine of senior newsroom professionals. Previously, they would transmit information to feed the newspaper's site, which is different from the new routine, in which they had to learn that Valor Pro is the company's priority, without forgetting that the next day's printed newspaper demands quality journalistic production, especially since the readership is specialized. There are 28 people at the Brasilia office, including the newspaper's deputy director, a management team and two editorial secretaries.

Since the 1990s, Folha and Globo have always had, in Brasilia, journalists devoted exclusively to the sites, who also use some of the material produced by the newspaper's reporters. Folha has three exclusive, online reporters with their own routine, who report directly to the team in São Paulo, to whom they transmit their texts and reports by internet or telephone. The newspaper's reporters adopt the same procedure. They are required to send up-to-date news and are even instructed to do this.

O Globo has two professionals who remain at the Brasilia newsroom, receiving notes and information from the newspaper's reporters or producing their own texts based either on information available online or that they gather. In general, material from Brasilia that is put online goes firstly via the local newsroom, where newspaper coordinators also produce and retransmit news when the workload is too heavy for the two sector journalists. Here, the newspaper's team 
also knows that they need to work quickly to feed digital media. Today, Globo has 22 reporters, three photographers, plus the coordinators for politics, national affairs, economics, photography and the editor-in-chief at the Brasilia office.

Initially, in the 1990s, when newspapers began requiring from professionals that they contribute to sites by transmitting news flashes, resistance was considerable. The argument posited by a union with more power and representativity was that the new model for journalistic companies would involve more work without pay rises. This resistance was overcome by the reality of the market, which had far more available professionals than jobs. Companies simply amended contracts with senior employees, who ended up ceding the intellectual property rights regarding their work, which companies used for diverse purposes. Those who did not accept the new era left and that was the end of the matter. Future professionals know from the outset that they will have to do whatever is asked of them for the newspaper, site and other specialized services. Further, the new configuration of the newsrooms has changed radically the production routine of journalists, compared with the one they experienced no more than two decades ago.

At Estado, all the reporters work for the printed publication Broadcast, and the newspaper's and agency's sites. They try to divide up work, leaving political and national affairs (education, health and work, amongst others) to the newspaper and economic affairs to AE, whose professionals share the same newsroom with work stations located sideby-side. In Brasilia, this coverage has historical origins, as AE set up its workforce to cater for Broadcast and hired experienced journalists in the field of economics and finance, so as to provide quickly the information demanded by or relevant to, clients. This material was also used for the printed publication and the tradition thus remained, along with coverage of political and national affairs, which are the privilege of the newspaper's professionals.

In Brasilia, more rigid planning of offices to operationalize daily activities begins the day before, when it is already necessary to know what will happen in advance and how proceedings might unfold, and take account of unpredictable news that emerges throughout the day. Continuous follow-up makes it possible to define the next day's printed edition. At all the newspapers examined in this study, the reporters responsible for diverse coverage have to send their flashes and be prepared to produce a text for the newspaper by the end of the day, unless editors deem that certain topics have been overdone and do not 
warrant space in printed publications.

In practice, the following day's newspaper is intended to provide readers with subject matter that is "more complete, rich in information and more contextualized", as defined by João Bosco Rabelo. Significantly, this is not always feasible due to space restrictions or insufficient time for reporters, who may have spent the whole day working on the sites and "overrun" the printing department's deadline. In arriving on the market at the beginning of the year, Valor Pro introduced an innovation. Reporters are instructed to write and send immediately to the headquarters in São Paulo one line of text capturing the essence of the information they received. They then send more complete material within 15-20 minutes at most.

Vehicles have more rigid routines for following certain events, for instance collective interviews. Reporters are obliged to pass on information by email or telephone as interviewees speak. For example, in interviews such as those at the Finance Ministry or with the president of the Central Bank, discussing pertinent issues, newsrooms send two or even three reporters, depending on the case. While one watches part of the interview and writes on a laptop or transmits information by telephone, the other follows what is said and does the same when the first reporter returns, working alternately until the end.

However, there are important cases in which it is not possible to send two reporters and the person who is present cannot leave the interview in case they miss something important or lose track of the context. These occasions usually entail direct television transmission, mostly via the government "Brazil Communications Company" (BCC). Someone from the Brasilia newsroom then assumes the task of producing and sending notes, while the reporter watches the entire interview in order to produce a more elaborate, final text.

As Cláudia Safatle explains, "young employees are very good" at covering interviews and other subjects for sites in this way because they master technology better than the more senior professionals. However, what they do is not journalism but rather "stenography", copying what is said, according to the director at Valor, based in Brasilia. In fact, they perform almost the same tasks as stenographers who transcribe alternately, in full, excerpts from speeches by deputies and senators at the National Congress.

This stenography has cast doubt over the role of journalists or at least some of them. For Traquina, these professionals are "active participants in defining and constructing news and, consequently, in the 
construction of reality", particularly with the growing influence stemming from "mediatic explosion", whereby it seems obvious that "journalists exercise power" (TRAQUINA, 2005:26).

Cláudia recognizes that the system of reiterating rapidly for digital platforms what is said during an interview in Brasilia is irreplaceable, at least for the moment. However, it is problematic for journalists who are new to the profession and used to passing on information mechanically, without time to understand the context, implications and unfolding. Since they operate within the pressure cooker of daily coverage, they have little or no time to reflect on and analyze what happened before. As a result, they are unable to produce texts that are more "adjusted", contextualized or reflexive. In the case of Valor in Brasilia, Cláudia states, staff try to keep at least Friday (usually quieter) available for reporters to produce texts calmly, with a certain level of reflection, to be published in the printed newspaper on the following Monday.

Experienced directors, coordinators and reporters interviewed for this study all stated that the greatest problem of "older workers" who are still at newsrooms is not the duty to produce flashes or pass on notes throughout the day but coping with what they call the paraphernalia of digital tools, especially when transmitting material. Most still complain, though some have adapted perfectly.

Cláudia Safatle, who has been a journalist in Brasilia since the mid-1970s, described an episode that illustrates the problem well. In March 2013, she went to China as a Valor special reporter to cover the first collective interview of president Xi Jinping. She sent several notes throughout the day and ultimately a complete piece for the newspaper. Vera Brandimarte, the newsroom director in São Paulo, suggested that she go directly from China to South Africa to cover the 5th Brics Summit, involving the emerging countries Brazil, Russia, India, China and South Africa, in which President Dilma Roussef participated. She refused to go, arguing that she was the only Brazilian journalist present in China and that, without the pressure of competition, she could carry out her work calmly and effectively. In South Africa, explains Cláudia, "I would not be able to compete with this bunch of kids trained in real time. I still cannot. I have conformed but not adapted completely".

Newspapers try to counter-balance this phenomenon of "stenographer" journalists with more experienced professionals, who can contextualize and analyze. Although the instantaneousness of information is crucial, companies also need to have "some grey hair", explains Bosco Rabelo, pointing out that these professionals have 
more "experience, astuteness and guile" to avoid and correct mistakes or simplistic readings of certain information that young reporters are often guilty of. Globo has a policy of maintaining its older professionals who understand the company's culture. Staff are rarely fired from the newspaper, they leave if they wish, though they generally end up being replaced by younger employees, explains Diana Fernandes, the office's political coordinator.

Office coordinators and directors have sought explanations for the tendency to absorb younger staff into offices in Brasilia, where between $70-80 \%$ are under 40 . One reason might be the superior ability of young employees to use digital platforms and their enthusiasm in coping with these tools, as well as their obvious greater capacity to race around gathering and transmitting news instantaneously.

Journalists who are recent graduates and want to progress in the career almost always make do with lower salaries, contrary to company cost-cutting policies adopted years ago, as recognized by newsroom directors in Brasilia. When an older, highly paid reporter leaves, a younger one (sometimes two), is often hired with the same expiration date as the person who left, enhancing the process of the "juniorization" of newsrooms.

The obvious problem in reading any site is that, to a greater or lesser extent, news is released with mistakes -from spelling to the information itself- that, significantly, are not only attributable to young, inexperienced reporters but are also the result of the rush in the production process. Of course, well organized sites notice mistakes quickly and address them.

The reporters from the newsrooms analyzed in this study hold that, even with the routine rush, mistakes are less common in Brasilia as most produce news directly from the places where it surfaces, such as ministries and their related organs, Congress, the Judiciary or the Presidency of the Republic. They believe that there is less chance of making mistakes when speaking directly to sources, rather than searching for information via third parties, often copying from the Internet, as "seated journalists" do routinely (PEREIRA, 2004). The geography of Brasilia, with the three powers of the Republic concentrated in nearby buildings, facilitates the physical circulation of reporters.

"Seated" journalists work for the online publications, stay mostly in newsrooms and are not numerous relative to the total amount of people at each office. There are four such professionals who work alternately during the day at Agência Estado and two at O Globo. In 
Brasilia, a significant group of "seated journalists" is to be found at Correio Braziliense, using the material and information produced by the printed newspaper's team. However, in addition to the editor, they have three subeditors and 15 reporters/writers, including interns, who do not go out on the street. They work alternately at the newsroom on a daily basis to feed the newspaper's and Correio Web's portals, in order to provide services to readers, with a strong emphasis on the hundreds of public service examinations that take place annually in the capital.

Along with young people, women make up most of the staff at the newsrooms analyzed- around $60 \%$ of the overall workforce. This reflects a reality that begins at universities. For instance, the journalism course at the University of Brasilia had 291 students in the first semester of 2013, 191 of them female. Research through sampling completed recently by professors from the Federal University of Santa Catarina (to be published soon in a book)7, shows that $64 \%$ of the country's journalists are female and aged up to 30 . Within the Brasilia newsrooms analyzed, this profile of the new journalist is complemented by a degree in journalism, though it is no longer compulsory for the career in general.

The executive driector of Correio Braziliense, Ana Dubeux, holds a theory that she believes explains partly the lower age groups at newsrooms in Brasilia. In the city, there is considerable competition regarding public service entrance exams, which lead to stable jobs and high salaries. There are also jobs for those who do not sit these exams at many public, private and nongovernmental press offices of organizations based in the capital, offering higher compensation than most communication vehicles.

As Dubeux explains, quality of life is another important factor in this context. Employees from newsrooms generally do not work on weekends or national holidays and do not experience the daily stress of those who constantly chase news with little time. All these factors end up "robbing" more experienced professionals, not just because organizations offer attractive salaries but also because they want journalists who, as well as being able to perform journalism, know the city, the communication vehicles and their professionals, in addition to being mobile and dynamic.

There is no precise data on the job of journalists in the capital since many of them, especially those who work at public, private and third sector organizations, are hired as "legal analysts", "development analysts" and "social communication technicians", despite assuming journalistic duties. A survey carried out by Sant'Anna found 60,734 
journalists hired as such in the country, drawing on the Annual Social Information Report (RAIS), and 65\% work in what he terms "extranewsroom": communication services, the press offices of companies and organizations. (SANT'ANNA, 2009).

\section{THE SCOOP “SYNDROME” IS ALMOST OVER}

Initially, one of the great handicaps for news sites was that they used material from newspapers, which, in turn, were preoccupied with stiff competition to provide "scoops", first-hand, exclusive information that could not, under any circumstances, be aired before circulating in printed publications. Times have changed. At Estado and Valor, reserving exclusive stories for printed material the following day is no longer allowed. Firstly, exclusive information goes immediately to Broadcast and secondly, to Pro, then the sites. Older journalists still complain: "What about my scoop in tomorrow's paper? Competitors will see it and publish it at the same time". The concept of scoop has changed a lot, as Bosco Rabelo states: "Information and subscribers are the priorities, competition is not placed above readers who pay". Cláudia Safatle explains that at Valor, everyone needs to be aware that, according to the previous conceptualization, scoops "ended the moment the company decided that its priority was Pro".

As Safatle points out, scoops still exist but they last only a few seconds rather than 24 hours like before, when stories would be subject to competition the day after publication. She often says to bitter reporters: "Take comfort from the fact that the scoop is yours, that you were the first to inform on the Internet". Reporters from Valor complain even more if they get the scoop on a Friday. Since the newspaper is not distributed on weekends, the news is made available on Pro, the site, and treated on that Friday and Saturday by competitors. When the newspaper is distributed again on the following Monday, it is unlikely there will be anything novel. From discussions with young reporters, it is clear that the new generations operating in Brasilia are not particularly concerned about printed scoops. They are more interested in scoops on digital platforms, which provide them with quick answers, sometimes instant fame, depending on the importance of the subject matter.

In the case of Folha and Globo, scoops are still accorded importance. Igor Gielow argues that due to the ever-intensifying convergence between printed and digital media and the generalized charging for services, the different media tend to offer the same products. 
"If a subscriber pays for online access, why would they not be entitled to the same information in the following day's printed newspaper"?, asks the director, explaining that, in his opinion, the availability of the same products seems irreversible for the future, although Folha has its exceptions today.

For Gielow, the online realm is on its way to providing subscribers with the same material they would read in printed publications, only more "diluted". News is released as events happen and information is gathered. This does not necessarily signify the end of printed newspapers, since people operate at different paces and not everyone has the eagerness to see all the news or any news immediately online. Some prefer to read more calmly the next day. Such readers want more complete and contextualized news, which newspapers need to deliver.

If there is an exclusive story that competitors cannot obtain, it is kept for printed publications and only put online the following day. Sometimes, the scoops exist but only some information is provided online, reserving the main story for the next day. It is a case-by-case decision, which can lead to the conclusion that a scoop obtained in the middle of the afternoon, for example, will not remain exclusive until the morning of the following day. It is then released, reveals Gielow.

He explains that there is still a deliberate policy on the part of the newspaper to try to include in printed publications scoops that reverberate, as illustrated by the interview that José Dirceu, Lula's former chief of staff, granted to the program which Folha maintains in partnership with TV Uol. He stated that the Minister Luiz Fux had harassed him and pledged personally to absolve him in the "mensalão" (big monthly stipend) trial at the Supreme Court, if he were appointed Minister. The recording was made on Tuesday, April 9th in São Paulo, by the reporter Fernando Rodrigues and the columnist Mônica Bergamo, both from Folha. Certain extracts could easily have appeared on the site but this would have caught the attention of competitors and weakened the impact of the scoop in the following day's newspaper. Thus, it was not disclosed.

Globo's policy is similar to that adopted by Folha but less rigorous. Any exclusive material must go on the site with the opening section or part of the story to be printed, even if it is at 10 or $11 \mathrm{pm}$, so that competitors have no more time to gather information and find themselves forced to cite the newspaper as their source. In general, these online texts attract interest regarding the following day's printed publication. 
The integration of office newsrooms with radio and television operations at the headquarters is still incipient and no office has a short-term expansion project. In all cases, journalists make rudimentary recordings at the newsroom, with scarce technical resources and material, when producing relevant stories that "deserve" to have online videos posted about them, to be divulged. Radio has reached none of them.

Globo's Brasilia newsroom seeks to be slightly more imposing, attempting to convince reporters that TV is part of the newspaper's site and that all should therefore cooperate in order to "value" the story to be printed. The newspaper has its own portable cameras that reporters and photographers carry for some reports to perform shooting. At other times, they use their cell phones. A certain culture is under construction and some enthused reporters do not hesitate to record videos of the content of their stories or use their cell phones, explains Diana Fernandes. However, for the time being, the rigor that exists in the newsrooms analyzed is stimulation to produce videos, not an imposition.

In compiling the information discussed here, which, as mentioned above, is part of a broader study, there was constant recognition of a phenomenon provoked by factors like the reduction in the number of professionals at newsrooms, the tendency to hire more young employees without experience and the rush to deliver information to readers as quickly as possible: the quality of the information transmitted to the public. This phenomenon has also been encountered in other countries and warrants more profound and systematized investigation, which lies beyond the scope of this study.

\section{NOTES}

1 Interviews were conducted with: the Brasilia office directors João Bosco Rabelo (Estado) and Igor Gielow (Folha); the deputy newsroom director for Valor Econômico, Cláudia Safatle, and the newsroom director, Rosângela Bittar; the political coordinator for O Globo, Diana Fernandes; and the executive editor at Correio Braziliense, Ana Dubeux; as well as the portal editor at Correio and Correio Web, Maria Júlia.

2 As some reporters preferred not to be identified, it was decided that all names should be omitted. Three of the 12 reporters were interviewed by telephone.

3 The information used in this text is taken from an unofficial translation of the book produced by students of Professor Zélia Leal Adghirni, drawing on seminars from the research line "Journalism and society", part of the 
postgraduate program of the communication department at UnB. The book, which is undergoing final translation and revision phases, will be published in Brazil.

4 The author of this work was the Brasilia office newsroom director of the Estado group between 1988-1990 and participated in the discussions on the initial project for the implantation of digital products.

5 O Globo: 12/04/2013, Globo Tecnologia - http://oglobo.globo.com/ tecnologia. Accessed on 13/04/2013.

6 There are several bills treating the subject in Congress, the last of which was presented at the end of January by the deputy Anthony Garotinho, from PR - RJ.

7 The profile of Brazilian journalists: demographic, political and work characteristics, was a study conducted in 2012, with a sample of 2,731 journalists, by the professors Alexandre Bergamo, Jacques Mick and Samuel Lima.

\section{REFERENCES}

ADGHIRNI, Zélia Leal. Mudanças Estruturais no Jornalismo: Travessia de uma Zona de Turbulência. IN PEREIRA, Fábio, ADGHIRNI, Zélia Leal, MOURA, Dione (orgs). Jornalismo e Sociedade -Teorias e Metodologias. Florianópolis: Insular, 2012.

ADGHIRNI, Zélia, PEREIRA, Fábio Henrique. O Jornalismo em Tempos de Mudanças Estruturais. Porto Alegre: UFRGS, Intertexto, Vol. 1. N² 24, 2011.

BRIN, Colette, CHARON, Jean, BONVILLE, Jean - Nature et transformation du journalisme - Théorie et recherchés empiriques. Quebec: Les Presses de L'Université Laval, 2004.

FONSECA, Virgínia P. da Silveira; KUHN, Wesley. Jornalismo Contemporâneo: Apontamentos para Discutir a Identidade Profissional. Porto Alegre: UFRGS, Intertexto, Vol 2, $\mathrm{n}^{\circ}$ 21, 2009.

JORGE, Thais de Mendonça e ADGHIRNI, Zélia Leal. Prática Profissional, Convergência e Perfil do Jornalista. Brasília: Observatório Mídia \& Política, 2010. Available at: em www.midiaepolítica.unb.br. Accessed on 20/10/2012.

JORGE, Thais de Mendonça. A Notícia em Mutação. Estudo sobre o Relato Noticioso do Jornalismo Digital. Brasília: Tese de doutorado, Faculdade de Comunicação da Universidade de Brasília, 2007.

JORGE, Thais de Mendonça; PEREIRA, Fábio Henrique. Jornalismo On-line no Brasil: Reflexões Sobre o Perfil do Profissional Multimídia. Porto Alegre, Famecos, 2010.

MORETZSOHN, Sylvia. Jornalismo em Tempo Real. Rio de Janeiro: Revan, 2002.

MÜLLER, Carlos. A Crise Estrutural dos Jornais e o Surgimento das Mídias Digitais: Impactos Sobre a Produção Jornalística. IN PEREIRA, Fábio, ADGHIRNI, Zélia Leal, MOURA, Dione (orgs). Jornalismo e Sociedade Teorias e Metodologias. Florianópolis: Insular, 2012 
NEVEU, Eric. Sociologie Du Jornalisme. Paris: La DéCouverte, 2001

PEREIRA, Fabio Henrique. O Jornalista Sentado e a Produção da Notícia Online no Correio Web. Porto Alegre: UFRGS, Revista em Questão, v. 10, nº 1, 2004.

RENAULT, David. O Jornalismo Sem Diploma e o Mercado de Trabalho. In: PEREIRA, Fábio; ADGHIRNI, Zélia Leal; MOURA, Dione (Orgs). Jornalismo e Sociedade - Teorias e Metodologias. Florianópolis: Insular, 2012.

RUELLAN, Denis. Corte e Costura do jornalismo. São Paulo: Libero, ano IX, $\mathrm{n}^{\circ} 18,2006$.

SANT'ANNA, Francisco. Mídia das Fontes - Um Novo Ator no Cenário Jornalístico Brasileiro. Brasília: Senado Federal, 2009.

TRAQUINA, Nelson. Teorias do Jornalismo - Porque as Notícias São Como São. Florianópolis: Insular, 2005

WOLF, Mauro. Teorias da Comunicação de Massa. São Paulo: Martins Fontes, 2008.

WOLTON. Dominique. Pensar a Comunicação. Brasília: Ed. UnB, 2004.

David Renault Holds a bachelor's degree in Journalism and worked at O Estado de S. Paulo, Correio Braziliense and the magazines Afinal and Exame between the 1970s and 1990s. He also has a Master's in Communication, a PhD in History, and has been a professor in the Communication department at the University of Brasilia (UnB) since then, assuming the post of head of department in 2007. E-mail: renault.david@gmail.com

RECEIVED ON: 28/09/2013 | APPROVED ON: 11/11/2013 
